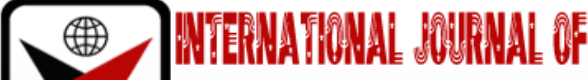

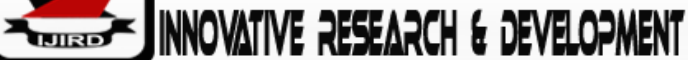

ISSN 2278 - 0211 (Online)

\section{Taxpayers' Education: Enhancing Tax Compliance in the Informal Sector of Nigeria}

Oloyede, Funmilayo Lizzy
Department of Political Science and Public Administration
Babcock University, Ilisan-Remo, Ogun State, Nigeria
Nwachukwu Joel
Department of Political Science and Public Administration
Babcock University, Ilisan-Remo, Ogun State, Nigeria

\begin{abstract}
:
Governments need tax revenues to finance developmental initiatives for the benefits of the citizens who operate both in the formal and informal sectors. While taxes are easily collectible from the formal sector, there exists a lot of challenge collecting taxes from the informal but dominant sector because players in the sector are neither organized or educated enough to appreciate the essence and benefits of paying taxes. This study sought to determine the impact of taxpayers' education and enlightenment on tax compliance by operators in the informal sector. The survey method was adopted with a population of 19,383,447 from twelve states of Nigeria while the sample size of 400 was determined using the Taro Yamane formula. The study found a positive relation between the level of taxpayers' education and tax compliance. The study therefore recommends that taxpayers' education and enlightenment should be carried out regularly by State Boards of Internal Revenues across the country.
\end{abstract}

Keywords: Tax education, tax knowledge, informal sector, Non-compliance

\section{Background}

The government requires tax revenue to carry our responsibilities imposed on it by the social contract with the citizens. As a result, the government is legally empowered to impose taxes on the citizens and corporate entities. The contribution of tax to gross domestic product (GDP) in Nigeria was put at 6.3\% in 2018 compared to African average of $16.5 \%$ (OECD, 2020). This has been attributed to the dominant size of the informal sector in Nigeria (Alabede, 2014).

Tax compliance in the informal sector of Nigeria is very low because most of the operators of private businesses in the informal sector default in tax payment. Alabede (2014) agreed that tax non-compliance opportunities are greater in occupation of self-employment, while Animasaun (2016) further established that most self-employed workers hardly fulfil obligation of tax compliance to the government. Rather, they have constituted a major problem to tax administration in Nigeria. In their study, Anyaduba and Balogun (2018) found that many of the informal sector business operators are not yet in the 'tax net'. These operators, according to them, have escaped the shield or cover of taxation because the income they generate in the sector, do not have place in the 'tax net'. Yet Chrisia (2014) rated the sector as the principal driver of the economy in most African economies, absorbing large population who are not engrossed in white-collar job. Evidence have shown that Nigeria alone has over 2 million citizens whose livelihoods depend on the informal sector, in businesses involving activities such as petty trading, farming, shoe making, entertainment, transportation and even repairing jobs such as mechanics, vulcanizer and horologist (SMEDAN \& NBS, 2017). If this large percentage of the informal sector in the economy has a high rate of tax non-compliance, this would continue to constitute great challenge for adequate tax revenue generation in the country, causing leakages in government revenue (Onwen, 2013; Umar, Derashid, \& Ibrahim, 2016; CISLAC, 2018; Ogunwede, 2018).

Tax non-compliance among the operators of informal sector in Nigeria has remain a major challenge to the government because its finances are shrinking in the face of increases in responsibilities. (Udoh, 2015; Osemeke, Nzekwu, \& Okere,2020). There is need to find out if the observed lack of tax knowledge and awareness about their obligation to pay income tax are responsible for the prevalent high rate of tax evasion in the informal sector in Nigeria. The objective of this study was to find out whether the operators of informal sector have adequate tax knowledge and were also aware of their sector's income tax obligation to tax authorities. It also sought to know whether adequate tax knowledge can create voluntary tax compliance in the informal sector and lastly, to find out if taxpayers' wellbeing can be enhanced by tax knowledge.

The remainder of this paper is segmented into five sessions. The second session is on the literature review while the third is on methodology. The fourth session discusses the findings while the fifth contains the conclusion and recommendations. 


\section{Literature Review}

\subsection{Tax Knowledge}

Tax knowledge refers to what the taxpayers know concerning all aspects of taxation. It is about their awareness and information on tax matters ranging from amount to be remitted, when to remit, mode of remittance, law and policy related to taxation and even many more aspects of taxation. Oti and Usang (2018) declared that tax knowledge includes taxpayers' awareness of various taxes, including awareness on any relief available to taxpayers and also acquaintance with tax computation for correct calculation and reporting of taxable income due them. Deloitte (2015) stated that it is necessary that taxpayers possess adequate tax knowledge, understand the tax system and procedures, be aware of their compliance obligations and be willing to comply by the provisions of the tax legislation. Oladipupo and Obazee (2016) also referred to tax knowledge as a process by which taxpayers become aware of tax legislation and other tax related information.

Tax knowledge is an important factor that influences tax compliance through tax administration. It has a significant effect on tax compliance which, in turn, affects revenue collection for the government at all levels (Palil \& Mustapha 2011). Umar, Derashid and Ibrahim (2016) found out that, adequate tax knowledge of taxpayers provided through tax administration has a positive influence on tax compliance. In this vein, Oti and Usang (2018) noted that tax knowledge is paramount to tax compliance and in order to secure tax compliance, tax knowledge must be made strong. Ogunwede (2018) recorded that tax knowledge is a way of encouraging taxpayers to be more cautious in completing their tax returns, and it is advantageous as the prior knowledge in taxation would save them the cost of employing the services of tax consultants to compute taxes for their businesses.

\subsection{Tax Education}

Taxpayers' education can be described as a method of educating the people about the whole process of taxation and why they should pay tax. Taxpayer education assists taxpayers in meeting their tax obligations to the government. The primary existence of taxpayer education is to encourage voluntary compliance amongst taxpayers (Hassan, Nawani, \& PutehSalin, 2016). Educated taxpayers appear to cooperate more with tax authorities since they have basic or core education of taxation and benefits that arise through revenue generation to finance public services. In view of this, Oladipupo and Obazee (2016) suggested that education on taxation should be included by government in school curriculum in order to increase people's knowledge taxation such that they pay tax willingly. When tax education is taught from foundation level in schools, there is hope for rich knowledge of it as individuals who learn from tender age and through phases of learning in school would know the impact of taxation and the necessity for fulfilling their obligatory role. Oloyede, Kupoluyi, Oyedokun and Benjamin (2017) also noted that the regulatory bodies should provide adequate knowledge to the taxpayers in the informal sector on salient issues pertaining to taxation. Adequate information relevant to taxes in their category would help in ascertaining tax liabilities and actual taxes to be paid.

The findings of Adimasu and Daare (2017) indicate that voluntary tax compliance would be attained if tax authorities create different tax awareness about taxation to sensitize taxpayers on the need and benefit of paying tax. Study on tax education and tax compliance among small and medium scale enterprises (SMEs) in Edo state Nigeria by Anyaduba and Balogun (2018) recognized a positive relationship that exist between stakeholders' sensitization programme on tax education and tax compliance among SMEs. In other words, sensitization of taxpayers through various programmes that provide tax education would not only make the citizens to remit their taxes but also encourage voluntary tax compliance among them.

\subsection{Informal Sector}

The informal sector is all-encompassing term that refers to the numerous aspects of a country's economy that are not taxed or monitored tightly by any form of government and are not included in the GDP of a country (Ruzek, 2015). CISLAC (2018) described informal economy as the sum total of economic activities that happen outside state regulation, which is neither taxed nor represented in a country's GDP. It also refers to economic activities that lack conventional accounting procedures, which are characterized by high incidences of non-reporting or underreporting and excluded from social measurement apparatus such as the GDP. Unlike the formal economy, economists do not include the informal sector's components in GDP computations (Market Business News, 2019). Wedderburn, Chiang and Rhodd (2019) noted that, in the informal sector, workers are, most often, not professionals; rather they are self-employed, paid or unpaid, help in family enterprises, or workers in domestic settings such as housekeepers and gardeners.

Taxation of informal sector has been almost universally unsuccessful (Obara, \& Nangih 2017). Tax evasion is very rampant as income is unmeasured and unrecorded. Their income on daily, weekly or monthly basis are not known because such are not declared by them. The informal sector has larger proportion of the population, but their actual number is not known and the amount they earn is undisclosed, a situation that makes it difficult for the government to value the taxes for them to pay, based on their incomes (Ogbuabor, \& Malaolu 2013). Therefore, their impact in contributing to government revenue through taxation is not felt.

Enugu Platform on Tax Justice (2017) revealed that a major factor to low Tax GDP ratio was the fact that the informal sector is not effectively captured in the tax net. Informal sector in Nigeria is very complex and presents challenges of revenue mobilization for tax authorities. Aina, Aderibigbe, Adigun and Oyedokun (2018) noted that, yearly Nigeria loses over \$15trillion to tax evasion yearly, which is as a result of tax avoidance especially in the informal sector in the country. 


\subsection{Tax Compliance}

Marti (2010), observed that tax compliance is a complex term to define; it has to do with the ability of the people to abide by the principles of tax administration in a country. Therefore, tax compliance is the degree to which a taxpayer complies or fails to comply with tax rules and regulations guiding taxation in his country (Sarker, 2003). Individuals do not like to pay tax to the government most especially when they do not have perfect information about how their tax remittances are spent (Listokin, \& Schizer 2012). Paying taxes is not particularly easy anywhere in the world for anyone who has struggled to earn income. People expend time, energy and other resources to earn the income and at the same time to not enjoy the social benefit of taxation; hence people will avoid paying taxes if they can (Oyedele, 2016).

Tax voluntary compliance has not taken root in Nigeria (Appah, \& Ogbona 2014) and it is a universal phenomenon that hinders efficient tax revenue productivity in both developing and developed countries (Alabede, 2014; El-Maude, Abdulsalam, Mustapha, \& Oginni, 2014). The degree of non-compliance may be measured in terms of the 'tax gap'. This represents the difference between the actual revenue collected and the amount that would have been collected if there was 100 per cent compliance (James, \&Alley 2014).

\subsection{Relationship between Tax Knowledge and Tax Compliance}

Tax knowledge is seen to have great significant impact on tax compliance: the more citizens lack knowledge or education about taxation in the country, the greater the desire and the opportunities for tax evasion (Worlu \& Emeka 2012). In the same vein, El-Maude, Abdulasalam, Mustapha and Oginni (2014) also stated that if taxpayers lack adequate tax knowledge, it may affect tax compliance. Lateef, Saheed, \& Onipede (2015) also established strong relationship between taxpayers and tax awareness. Their study found out that low level of tax compliance is caused by insufficient awareness on tax regulations and also showed that tax compliance determinants are the factors that influence taxpayers to or not to comply with the provisions of tax laws. Mukhlis, Utomol and Soesetio (2015) observed that tax education has a positive and significant impact on tax knowledge, as tax knowledge has proven to be significant and have positive effect on tax compliance. This outcome shows that the strengthening of the tax education is very important in shaping the tax knowledge, so that it can increase tax compliance.

Hassan, Nawawi, Azlin and Salin (2016) avow that tax education remains a central focus to the tax authority, and the tax agency is committed to educating taxpayer in every possible way. The study also maintains that greater level of taxpayer knowledge will directly be linked to the probability of tax compliance and confirmation with tax requirements. This is because better educated and knowledgeable taxpayers have more awareness on their obligation and duty as a good citizen, better understanding of tax mechanism and have higher level of moral and good behaviour. These characters encourage more positive taxpayer attitude, and hence improve compliance. Hastuti (2014) in laying serious emphasizes on tax education, said that tax is an important subject to be learnt in high education since nobody could escape from it and as potential taxpayers, the students also need to know what and how the obligation to calculate, pay and report their own taxes would be done.

Nwidobie and Oyedokun (2018) stated in the findings that the greater the tax knowledge of the society, the advanced it will be able to have a substantial influence on the achievement of a sense of tax justice for the community. This will, in turn, influence and raise sense of tax justice which will increase tax compliance in the community. Likewise, it would influence the level of knowledge of the higher taxes, thereby creating adequate awareness of the people towards their tax obligations. Therefore, knowledge of taxation can be built from the tax education received by the community. Mascagni, Santoro and Mukama (2019) opined that the government's responsibility is to provide educative programme in terms of information and training for taxpayers in order to increase taxpayer knowledge and compliance behaviour.

The study of Hassan, Nawawi, Azlin and Salin (2016) found that text-based information such as pamphlets, advertisement and website appear to be effective ways to enlighten the taxpayers to comply with tax requirements, because the methods are very convenient with the taxpayer. This is unlike when specific tax programmes are organized in particular locations which would require taxpayers to sacrifice their time and incur costs to attend which would lead to low attention. These methods are also perceived effective as a tax education medium, but the most preferred medium desired by the taxpayers is through the media such as radio and television.

\section{Methodology}

The survey method was utilized in gathering data from respondents to the study. The respondents comprised taxpayers in the informal sector in Nigeria drawn from the six geopolitical zones in the country (two states were selected from each zone to administer questionnaire to the operators of informal sector) and the tax officials in the six selected State Internal Revenue Board (SIRB) in Nigeria. The respondents were selected for the exercise in order to reveal how well tax education is carried out and received by those concerned. The population was 19,383,447 from which a sample size of 400 was drawn, which was calculated and determined by Yamane (1967) formular. The questionnaires were placed on a five-point Likert Scale and 381 out of 409 copies were received within three (3) months of distribution and analysed. The response rate was 95.25 . 


\section{Data Analysis}

\subsection{Analysis on Knowledge of Tax among the Operators of Informal Sector in Nigeria}

\begin{tabular}{|l|c|c|c|c|c|c|c|c|}
\hline $\mathbf{S} / \mathbf{N}$ & Question Items & SA & A & D & SD & U & Mean & St.D \\
\hline $\mathbf{1 .}$ & $\begin{array}{c}\text { State Internal Revenue Service regularly } \\
\text { organizes tax education programme to } \\
\text { educate taxpayers on the benefits of tax } \\
\text { and file their returns on time. }\end{array}$ & $\begin{array}{c}66 \\
(17.3)\end{array}$ & $\begin{array}{c}128 \\
(33.6)\end{array}$ & $\begin{array}{c}128 \\
(33.6)\end{array}$ & $\begin{array}{c}53 \\
(13.9)\end{array}$ & $\begin{array}{c}6 \\
(1.6)\end{array}$ & 2.5118 & .98568 \\
\hline $\mathbf{2 .}$ & $\begin{array}{c}\text { Voluntary tax compliance can be attained } \\
\text { with adequate tax knowledge/education }\end{array}$ & $\begin{array}{c}89 \\
(23.4)\end{array}$ & $\begin{array}{c}264 \\
(69.3)\end{array}$ & $\begin{array}{c}25 \\
(6.6)\end{array}$ & & $\begin{array}{c}3 \\
(.8)\end{array}$ & 3.1444 & .59174 \\
\hline $\mathbf{3 .}$ & $\begin{array}{c}\text { Tax education and knowledge can } \\
\text { improve wellbeing of taxpayers. }\end{array}$ & $\begin{array}{c}75 \\
(19.7)\end{array}$ & $\begin{array}{c}200 \\
(52.5)\end{array}$ & $\begin{array}{c}80 \\
(21)\end{array}$ & $\begin{array}{c}7 \\
(1.8)\end{array}$ & $\begin{array}{c}19 \\
(5)\end{array}$ & 2.8005 & .94429 \\
\hline
\end{tabular}

Table 1: Assessment of Respondents' Tax Knowledge

Table 1 presents the result of the respondents' responses on the research objective measuring the knowledge of tax among the operators of informal sector in Nigeria. The analysis depicts that one hundred and ninety-four (194) respondents, representing $50.9 \%$ of the total responses agreed to the view that the State Internal Revenue Service regularly organizes tax education programme to educate taxpayers on the benefits of tax and file their returns on time. Total number of one hundred and eighty-one (181) respondents representing $47.5 \%$ disagreed with the view. However, six (6) respondents, representing $1.6 \%$ of the total responses, remained neutral.

The analyses support the view that voluntary tax compliance can be attained with adequate tax knowledge and education. This view was shared by three hundred and fifty-three (353) respondents, representing $23.4 \%$ of the total responses while twenty-five (25) respondents, representing 6.6\% disagreed with the view point. Three (3) respondents representing $.8 \%$ were neutral. This result implies that with regular and adequate tax knowledge in terms of tax orientation, education and various tax awareness programmes, voluntary tax compliance would be attained among the operators of informal sector. On the proposition on whether tax education and knowledge can improve wellbeing of taxpayers, two hundred and seventy-five (275) respondents, representing $72.2 \%$ of the total responses agreed to the view, while eighty-seven (87) representing $22.8 \%$ disagreed and nineteen (19) remained neutral. This implies that if adequate tax education and knowledge are passed on to informal sector operators, such enlightenment on the need and benefit of paying taxes, would improve their wellbeing and improve standard of living especially if the government delivers on its responsibilities with taxes collected.

\subsection{Responses from the Tax Officials}

Does the SIRB in your domain provide tax knowledge on Income Tax to the operators of informal sector in the state or create awareness on self-assessment to the categories of taxpayers in the informal sector?

In Lagos state, there is an effective unit known as Tax Education and Enlightenment Scheme which gives enlightenment on tax payment, works in collaboration with tax officials in the market by moving round to meet traders in sensitizing them on tax related matters. They often go through traders' records to ascertain whether they remit their taxes regularly. Also, Lagos state undertakes advertisement both on electronic and print media through jingles on radio, 'tax talk' programme on Lagos Television (LTV), billboard on tax enlightenment, using actors and actresses to create awareness to the masses on television stations, tax information on internet, advertisement on daily newspapers and so on. The officials believe that they can still do more to raise the level of tax awareness in Lagos State in order to improve internally generated revenue.

In Oyo state, tax knowledge is regularly given in form of sensitization; public functions are organized to inform the citizens on what tax revenues are used for and the people are encouraged to also ask questions for more understanding in every such forum. A programme on tax public forum was organized on the $28^{\text {th }}$ of January 2020 where the state governor and tax officials in the state met with informal sector operators and members of formal organizations like banks, production and manufacturing associations, to address stakeholders' questions and give more enlightenment on taxation. An interviewee noted that majority of illiterates are found in this sector and if you want to collect money from them, you would definitely meet and get them informed first. In addition, the tax administrators, officials and agents in the state often move round to give tax related education to the informal sector players. For adequate tax education, tax offices (Mini Tax Stations) are created in the markets while these units work in collaboration with another group called Tax education and Enlightenment Scheme to ensure tax compliance among the traders in the markets.

Kogi State Internal Revenue Board created Directorate of Tax Education, with the mandate of reaching out to people including players in the informal sector. Under this directorate, there is a tax education unit, where one-on-one sensitization is done between the agents and the operators of informal sector. Broadcasting is also done on radio, television, round the town and clusters. There are jingles in local languages and Pidgin-English because of the setup of the state as it comprises many languages. There is also a forum of Stakeholders' engagement, where meetings are called for the purpose of interaction. The medium is also used for education on the need to pay tax and as well as for tax administrators to listen to their challenges.

In Bauchi State, the SIRB affirmed that the issue of taxation in Nigeria is setting a new dimension for a friendly atmosphere to be created, in which tax administrators and taxpayers would operate and at the end achieve a win-win situation, as both sides get what they want. Tax awareness is important to encouraging people to pay tax towards the 
economy advancement of the country. As a result of this, the board have Public Media Programme (PMP) on radio and television stations, tag 'Taxpayers' Education'. This is done at a regular interval, on weekly basis, whereby a representative of the board and an official from internal board of revenue and other major stakeholders within informal sectors are invited to discuss vital issues in order to educate the general public on importance of paying tax, how tax can be calculated and period for the tax payment. In addition, the state revenue board does jingles, sends out bulk messages to citizen on their phones. The board is also on social media such as YouTube, Facebook and others. All these are in place to further enlighten the taxpayers in Bauchi state to have full knowledge of taxation. An interviewee stated that 'We have gone far in this area (creating awareness) in Bauchi state in order to achieve voluntary compliance'.

In Delta state the governor of the state at a time had called the informal sector operators for meetings, where the revenue board, on invitation gave tutorial to them on the need to pay tax. Fliers were distributed to the general public for sensitization. In remote areas, information on tax related issues is passed on from house to house. Tax education and encouragement are given, leaving the words such as, 'if others do not pay taxes, the benefit of taxation that are been enjoyed by you would not be possible', 'to whom much is given, more is expected' and by this, many have given themselves to compliance.

In Imo State Internal Revenue Board (ISIRB), tax education is paramount to collecting taxes in informal sector. The operators are educated on the need to pay tax and that it is stipulated in the constitution of Nigeria. Orientation on remitting certain percentage of their earnings is given, after these, enumeration and assessment are done. ISIRB gives tax knowledge through jingles, radio announcement, fliers, one-on-one visit and appointments with association when they have meetings. 'We educate them on what to pay and what not to pay so that there will be no room for anyone to take advantage of them'.

\subsection{Role of Tax Knowledge on Tax Compliance among Informal Sector Operators in Nigeria}

The second objective of this study was to examine the role of tax knowledge on tax compliance among the operators of informal sector in Nigeria. The findings of this study show a small difference between the number of respondents who agreed and those that disagreed that the SIRB regularly organize tax education programme to educate taxpayers on the benefits of tax and file their returns on time. Although the analyses indicate that adequate tax knowledge from SIRB to the operators of informal sector with a minor edge of $50.9 \%$ to $49.1 \%$, this implies that almost half of the sampled population have not experienced adequate and regular tax education from the SIRB in Nigeria.

The findings of this research work are consistent with the work of Oluseyi and Jim-Suleiman (2017) that there was no adequate education, awareness and cordial relationship between taxpayers and tax administrators in Plateau state of Nigeria. In other words, there was no channel to give enough opportunity for taxpayers to complain about tax assessment and other disputing issues on tax. This finding also shows that with regular and adequate tax knowledge in terms of tax orientation, education and various tax awareness, voluntary tax compliance would be attained among the operators of informal sector. Furthermore, tax education and knowledge can improve wellbeing of taxpayers. This implies that adequate tax education and knowledge passed on to informal sector operator would give more enlightenment on the need and benefit of paying taxes and when such benefit are provided, it would improve their wellbeing and improve their standard of living. Contrarily, the study of Nwidobie and Oyedokun (2018) found out that taxpayers in Nigeria receive adequate tax education via television, newspapers, radio, symposia, seminars, training sessions and personal (one-on-one) education. This analysis agrees with them that the best method to pass tax knowledge between the tax administrators and taxpayers is 'personal based' (one-on-one) as it gives personal interaction. In addition, symposia/seminars and training sessions for the taxpayer education bring about more enlightenment and further help to clear taxpayers' doubt through answering of questions that are put up across to qualified tax personnel. Taxpayers' fears are dispelled as their confidence has been increased through the education provided by the tax authorities.

\section{Summary of Findings}

The findings from this study revealed a small difference between those who agreed to and those who disagreed that adequate and regular tax knowledge from tax administration affects tax compliance by players in the informal sector. The implication is that many of the operators in the informal sector lack tax education or have not experienced adequate and regular tax education from the SIRB in Nigeria. However, information gathered from the SIRS visited for this study indicate regular and adequate dissemination of tax knowledge to the operators in informal sector. These were provided through tax education in the media, jingles, education and enlightenment of various trade union members and stakeholders' meetings, involving both the traders, artisans, business-owners and the government

\section{Conclusion and Recommendations}

Tax education is essential in achieving tax compliance. Therefore, in order for government to generate more revenue through tax from informal sector, the level of awareness and tax knowledge of the taxpayers in the informal sector through tax education must be improved as these have implications for tax compliance and tax revenue generation. Tax education must be of paramount importance to all SIRS to enhance and increase awareness of informal sector operators on the essence of taxation, benefits of taxation to the citizens and to the sector they belong, knowledge of how to calculate actual and due tax to be paid on their income. Such knowledge will help them to avoid been cheated by corrupt tax administrators. Seminars and conferences must be organized on regular basis with the union members in the local dialect's peculiar to the areas of location. Fliers and media programme on television and radio stations in English, Pidgin and local languages should also be printed and widely distributed to create more awareness. 


\section{References}

i. Adimasu, N. A. \& Daare, W. J. (2017). Tax awareness and perception of tax payers and their voluntary tax compliance decision: evidence from individual tax payers in SNNPR, Ethiopia. International Journal of Scientific and Research Publication, 7(11) 686-695.

ii. Alabede, J. O. (2014). 'An exploratory analysis of individual taxpayers' compliance behaviour in Nigeria: A study of demographic differences and impact'. International Journal of Accounting and Taxation, 2(2)39-64.

iii. Aina, L. A, Aderibigbe, T. A, Adigun, D. E. \& Oyedokun, G. E (2017). Tax morale and Nigeria's informal sector. Journal of Taxation and economic development. The Official journal of the Chartered Institute of Taxation of Nigeria, ISSN 1118-6017. 16(2).

iv. Animasaun, R. O. (2016). Tax administration and revenue generation: a perspective of Ogun State internal revenue service. International Journal of Innovative Finance and economic Research. 5(1) 11-21

v. Anyaduba, J.0. \& Balogun, J. E (2018). Tax education and tax compliance among SMESs in Edo state. Journal of Taxation and Economic Development. The official journal of the chartered institute of taxation of Nigeria. 17(1).

vi. Appah, E. \& Ogbonna, G. N (2014). Self-assessment science and revenue generation in Nigeria. Developing countries Studies, 4(10).

vii. Chrisa, I. (2014). The role of the informal sector in African regional integration: scope and limits.

viii. Civil Society Legislative Advocacy (CISLAC) (2012). Expanding the tax base in the informal sector in Nigeria.

ix. Deloitte (2015). Harnessing the bottom billions in the informal sector

x. https://www2.deloitte.com/content/dam/Deloitte/ng/Documents/tax/ng

xi. El-maude, J. G, Abdulsalam, M., Mustapha, N. \& Oginni, S. O. (2014). Tax complexity and tax compliance in African self-assessment environment. International Journal of Management Research and Review. 4(5)

xii. Enugu Platform on Tax Justice (2017). The realities of taxation of taxation in the informal sector in Enugu state. A Research presented by Enugu Platform on Tax Justice hosted by Justice Development Peace and Caritas, ENUGU DIOCESE (JDPC) Enugu Diocese in collaboration with CISLAC sponsored by OXFAM Nigeria

xiii. Hastuti, R. (2014). Tax Awareness and Tax Education: A Perception of Potential Taxpayers. International Journal of Business, Economics and Law. 5(1).

xiv. Hassan, N, Nawani, A, \& PutehSalin, A. S. Z. (2016). Improving tax compliance via tax education - Malaysian experience. Malaysian Accounting Review,15(2)

xv. James, S. \& Alley, C. (2004). Tax compliance, self-assessment and tax administration.

xvi. University of Exeter-Ore-Open Research Exeter. Journal of Finance and Management in Public Services. 2(2).

xvii. Listokin, Y. \& Schizer D. M (2012). I like to pay taxes: taxpayer support for current spending and the efficiency of the tax system. The Center Tax Law Review. 66, 179. Yale Law School. John M. Olin Center for Studies in Law, Economic, \& Public Policy Research Paper 456.

xviii. Lateef, O. M, Saheed, Z. S., \& Onipede A. Y (2015). Institutional factors and personal income tax compliance in Kaduna State-Nigeria. Research on Humanities and Social Science. 5(24), 146-157.

xix. Market Business News (2019). Informal sector definition and meaning. https://marketbusinessnews.com/financial-glossary/informal-sector-definition-meaning.

xx. Marti, L. O (2010) Taxpayer's attitudes and tax compliance behavior in Kenya. African Journal of Business and Management, 1, 112-122

xxi. Mascagni, G., Santoro, F., \& Mukama, D. (2019). Teach to Comply? Evidence from a Taxpayer

xxii. Education Programme in Rwanda. The International Centre for Tax and Development at The Institute of Development Studies, Brighton BN1 9RE, UK. ICTD Working Paper 91

xxiii. Mukhlis, I. Utomo, S. H., \& Soesetio, Y. (2015). The role of taxation education on taxation knowledge and its effect on tax fairness as well as tax compliance on handicraft SMEs sectors in Indonesia. International Journal of Financial Research, 6(4).

xxiv. Nwidobie, B. M. \&Oyedokun, G. E (2018). The effectiveness of tax education channels in

Xxv. Nigeria. AE-FUNAI Journal of Accounting Business and Finance (FJABAF)-A bi-annual Journal of the Department of Accountancy, Business and Administration, Banking \& Finance, Alex-Ekwueme Federal University of Ndufu-Alike, Ebonyi State Nigeria. 3(1)

xxvi. Obara, L. C. \&Nangih, E. (2017). Taxing the informal sector and revenue generation in developing countries: an empirical investigation from Rivers states of Nigeria. Journal of Accounting and Financial Management, 3(1)

xxvii. OECD (2020). Revenue statistics in Africa, 2020 - Nigeria. Downloaded from oe.cd/revenue-statistics-Africa on January 23, 2021.

xxviii. Ogbuabor, J. E, \& Malaolu, V. A (2013). Size and causes of the informal sector of the Nigeria Economy: evidence from error correction mimic model. Journal of Economic and Sustainable Development, 4(1).

xxix. Oladipo, A. O. \& Obazee, U (2016). Tax knowledge, penalty and tax compliance in small and medium scale enterprises in Nigeria. Business Journal 8(40), 1-9

xxx. Ogunwede, J. K (2018). Informal sector taxation and inclusive growth in selected states of south-west Nigeria. A Thesis Submitted in the Department of Accounting, School of Management Sciences. In Partial fulfilment of the Degree of Doctor of Philosophy. Babcock University, Ilisan Remo, Ogun State, Nigeria.

xxxi. Oloyede, F. L, Kupoluyi, A. K., Oyedokun, G. M, \& Benjamin, R. B (2017). Informal sector tax administration and monitoring in Nigeria. Journal of Taxation and economic development, 16(2),16-25; The Official journal of the Chartered Institute of Taxation of Nigeria. ISSN 1118-6017. 
xxxii. Oluseyi, A. V. \& Jim-Suleiman, S. L (2017). Capital gains tax administration and internally generated revenue in Plateau state, Nigeria. Journal of Taxation and economic development,16(2),1-15 The Official journal of the Chartered Institute of Taxation of Nigeria. ISSN 1118-6017.

xxxiii. Onwe, O. J. (2013). Role of the informal sector in development of the Nigeria economy: output and employment approach. Journal of Economic and Development Studies. 1(1), 60-74

xxxiv. Oti, P. A. \& Usang, O.E. (2018). Effect of voluntary assets and income declaration scheme knowledge, detection rate on VAIDS compliance: Evidence from Cross River State. Journal of Taxation and economic development, 17(2), 35-45; The Official journal of the Chartered Institute of Taxation of Nigeria. ISSN 1118-6017.

xxxv. Osemeke, N. Nzekwu, D., \& Okere, R. O (2020). The challenges affecting tax collection in Nigerian informal economy: case study of Anambra state. Journal of Accounting and Taxation. 12(2), 61-74

xxxvi. Oyedele, T. (2015). Insights on taxation and fiscal policy. A compendium of articles on tax,

xxxvii. Social security, business and the economy. Bloomsbury Professional Ltd, Maxwelton House, 41-43 Boltro Road, Haywards Health, West Sussex, RH16 1BJ

xxxviii. Palil, M. R. \& Mustapha, A.F (2011). Determinant of tax compliance in Asia: a case of Malaysia. European Journal of Social Sciences. 24(1)

xxxix. Ruzek, W. (2015). The informal economy as a catalyst for sustainability. Sustainability. 7, 23-34. Doi: $10.3390 /$ su70100023.

xl. Sarker, T. K. (2003). Improving tax compliance in developing countries via self- assessment system. What could Bangladesh learn from Japan? Journal of Asia Pacific Tax. 1.

xli. SMEDAN and NBS (2017) National Survey of Micro Small and Medium Enterprises (MSMEs). Lagos: FGN Press.

xlii. Umar, M. A., Derashid, C., \& Ibrahim, I. B. (2016). Income tax noncompliance in Nigeria and the moderating effect of public governance quality: a suggested framework. Mediterranean Journal of Social Science. 7(6),339348

xliii. Wedderburn, C., Chiang, E. P., \& Rhodd R. (2009). The informal economy in Jamaica: is it feasible to tax this sector? Journal of International Business and Cultural Studies.

xliv. Worlu, C. N., Nkoro, E. (2012). Tax revenue and economic development in Nigeria; a macro econometric approach. Academic Journal of Interdisciplinary Studies. (1)2. 